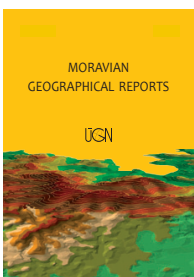

MORAVIAN GEOGRAPHICAL REPORTS

Institute of Geonics, The Czech Academy of Sciences

journal homepage: http://www.geonika.cz/mgr.html

doi: 10.2478/mgr-2018-0014

\title{
The impact of consumer green behaviour on green loyalty among retail formats: A Romanian case study
}

\author{
Dan-Cristian DABIJA a *, Brînduşa Mariana BEJAN a , David B. GRANT b
}

\begin{abstract}
Customer loyalty enables companies to outperform competitors and better satisfy customers' needs and desires. People today are increasingly interested in buying green or sustainable products, pursuing responsible consumption, getting involved in environmental protection activities and preserving resources. These key elements of sustainability are crucial in retailer strategies for approaching customers, strategies encompassing both communication and well-structured offers of sustainable, green and environmentally friendly products to gain customers' loyalty and assist them in adopting responsible (green) consumption behaviours. This may not be the case in all retail markets or sub-markets, however. This paper investigates these issues in the context of the emerging European economy of Romania, using a survey conducted in four major retail segments comprising more than 3,000 respondents. Using structural equation modelling the authors reveal that Romanian retailers are concerned with drawing customers and gaining their loyalty by adopting strategies based on the principles of sustainability. The results indicate that in this emerging market behavioural antecedents differ across the analysed retail formats in building green loyalty, which represents a challenge for retailers in their attempt to draw, satisfy and bind consumers to their retail formats and stores. At the same time, there is also a growing awareness of green aspects among Eastern Europeans, even if they have been challenged with sustainability issues and the need to adopt green behaviours more recently than their Western European counterparts.
\end{abstract}

Keywords: green behaviours, responsible consumption, sustainable products, green loyalty, retail formats, Romania

Article history: Received 17 September 2017; Accepted 25 July 2018; Published 30 September 2018

\section{Introduction}

The preservation of resources and environmental protection are much debated issues in developed societies, being consistently adopted by most organisations in such societies within their market strategies, but in countries with emerging economies such issues are still in their infancy. The rapid development of communication technologies in these emerging markets allows consumers not only to have access to global information, but also to understand the behaviour of their peers in the mature markets and to develop similar demands and expectations. Consumers in emerging markets strive to adopt sustainable behaviours as they are increasingly concerned with environmental protection issues, the reduction of resource consumption, the production of goods from renewable sources, etc. (Dabija et al., 2018) and prefer more and more products made from green, organic components with a low environmental footprint and contribution to pollution reduction (Dabija and Bejan, 2017).
The proper understanding of consumption preferences and relevant behavioural dimensions to determine customer loyalty is, on the one hand, a major challenge for retailers operating in emerging markets - represented mostly by global players and regional retail chains - and on the other hand, a pressing need to adopt the most appropriate market strategies. Based on this premise, this paper investigates behavioural antecedents contributing to the development of green loyalty in the Romanian retail market, through a comparative analysis of these dimensions in four retail formats: food, do-it-yourself (DIY), electronic and household appliances, and fashion and footwear. In so doing, this paper addresses the topic of consumption patterns, shopping habits and the shopping behaviours of a given population and its consumer preferences.

This paper is structured as follows. Following a literature analysis of the antecedents fostering green loyalty in food and non-food retail, in which special emphasis is placed

\footnotetext{
a Department of Marketing, Faculty of Economics and Business Administration, Babeş-Bolyai University Cluj-Napoca, Romania (*corresponding author: D. C. Dabija, e-mail: cristian.dabija@econ.ubbcluj.ro)

${ }^{\mathrm{b}}$ Hull University Business School, UK and Hanken School of Economics, Helsinki, Finland
} 
on green behaviour and its components, the proclivity for environment protection and on factors determining responsible consumption, the research methodology and operationalisation of hypotheses and methods of data collection are presented, with analysis of results and conclusions and contributions rounding out the paper.

\section{Literature review}

The rapid development of the retail sector and the rise in the number of competitors make the increase of customer trust and the attraction of customers to the stores more difficult (Fernie and Sparks, 2014). The main way for retail chains to address competition is mostly through offer differentiation, the proper satisfaction of consumers and the gaining of their loyalty. Loyalty is behaviour that can be observed and is reflected in consumers' attitudes and the way in which they advertise a company or a product through word-of-mouth recommendation (Garcia de los Salmones et al., 2005). Individuals may prove their loyalty to a company by repurchasing one of its products or services, by remaining immune to the marketing efforts of the other competitors (Sierra et al., 2015), as well as by recommending the company and increasing the frequency of visits and/or the purchased quantity of goods (Dabija and Băbuţ, 2012; Swoboda et al., 2014).

At present, there is movement by retailers and other firms towards becoming greener, more environmentally friendly and socially responsible. These concepts are often blurred as to their meaning and whether they all mean the same thing (Grant et al., 2017b). Thus, we adopt the definition of green retailing put forth by Lai et al. (2010) that stems from the natural resource-based view of the firm or NRBV (Hart, 1995). NRBV stresses a firm's relationship with the natural environment and highlights three strategic capabilities of the firm: pollution prevention, product stewardship and sustainable development. Green practices, involving these strategic capabilities, are valuable to firms in gaining sustainable cost and service advantages, and thus green retailing in this paper considers these practices in the context of the four 'green Ps' discussed in section 2.1 (Lai et al., 2010; Epuran et al., 2018).

The retailing literature deals more frequently with the role of green behaviour in the generation of customer loyalty towards the retail store (Kang and Hur, 2012; Asgarian et al., 2014; Dabija and Bejan, 2017). Therefore, loyalty represents a result of the interaction between green behaviour, the proclivity or propensity for environmental protection and responsible consumption.

\subsection{Green behaviour}

There is an increasing trend to exhibit green behaviour today. Being green is a process requiring major changes on the part of consumers, changes which are not only related to environment protection but also include the implementation of actions with a positive impact on an individual's health (Reshmi and Johnson, 2014). Consumers seem to be more willing to bring green products into their regular consumption, for example Fair Trade or organic food products and Forest Stewardship Council (FSC) wood products. Reshmi and Johnson (2014) define green products as those items with low negative impact on the environment, which do not affect people's health and are often made of recyclable, organic and green materials or contain biodegradable components. This opinion is also shared by authors who believe that green products should be produced through processes with a very low environmental footprint (e.g. Sarkis et al., 2010). Consumers who are more concerned with environmental protection tend to be more addicted to purchasing green products, which contributes to the creation of green behaviours (Kirmani and Khan 2016).

The extant research literature on this phenomenon is limited, particularly with respect to empirical studies. Furthermore, many authors simply consider green purchasing behaviour with respect to attitudes and product characteristics and do not consider satisfaction and loyalty. For example, Young et al. (2015) note that the key factors that will help green consumers purchase a more ethical technology product are:

1. the consumer's green values are strong;

2. the consumer has purchase experience;

3. the consumer has plenty of time for research and decision making;

4. $\mathrm{s} /$ he has good knowledge of the relevant environmental issues;

5. green products are reasonably available; and

6. the consumer can afford and is prepared for the financial costs.

Cherian and Jacob (2012) focused on green marketing and the need to shift a consumer's behaviour and attitude towards more environmentally friendly life styles. Their study was a compilation of various factors related to green marketing and presented a conceptual framework. Do Paço et al. (2016) examined the perceptions of 1,175 university students across England, Germany, Portugal and Spain to determine whether they will take environmental aspects into account when they buy something or in their daily behaviours. Their work was exploratory in nature, and they concluded that it is not yet possible to answer this question with a high degree of certainty, and thus the development of green consumer behavioural models is necessary.

From a conceptual perspective, Joshi and Rahman (2015) reviewed 53 empirical articles on green purchasing behaviour from 2000 to 2014: they found that a consumer's environmental concerns and the functional attributes of a product emerged as the two major determinants of consumer green purchasing behaviour. They suggested their work would help policy makers and managers in formulating and implementing strategies to encourage green purchasing. Lastly, Jaiswal and Kant (2018), building on Joshi and Rhaman (2015), conducted an empirical study to operationalise the relationship between cognitive factors directly and indirectly influencing green purchase intention via the mediating role of attitude towards green products, in an Indian context. They argued that their model also provides valuable inputs for policymakers and marketers to design green marketing policies and strategies.

The purchase of green products depends on an individual's attitude to the environment and its protection. Various studies have shown that there is a positive and quite strong relationship between customer satisfaction and her or his intention to purchase (Reshmi and Johnson, 2014). When the customer is content with the sustainability of a product, she or he will purchase that product and the satisfaction derived from purchasing and using it will pave the way for loyalty which, in turn, will be displayed by repurchasing such green products. The connection between green attitudes and green behaviour is dichotomous, which is best expressed in the 'all 
or nothing' approach adopted by some consumers (Johnstone and Tan, 2014). When making purchases consumers either follow the principle according to which all items should be environmentally friendly, or do not pay attention to issues like sustainability or concern for the environment.

An attitude towards and the desire to adopt a green behaviour also depends on how it is assessed and appreciated by the individual's friends and the society in which she or he lives. When green behaviour is assimilated into society as a social norm (i.e. universally accepted as a common practice), its impact on consumers is greater. Conversely, if green behaviour is not viewed as a common practice, consumers will not make changes to their life style to adopt this concept (Johnstone and Tan, 2014). From a marketer's viewpoint, an individual's increasing concern with the environment has contributed to the emergence of a new segment to be serviced - the so-called green consumers. These are consumers who make purchasing decisions based on the extent to which the product is made of green components or contributes to the protection of the environment. From a marketing perspective, green behaviour represents the concerted and synergetic interaction between the four 'green Ps', namely: green product/production, green pricing, green placement and green promotion (Kordshouli et al., 2015). When used synergistically, the four green Ps generate trust in green products, overall satisfaction and, in the end, green loyalty.

Green product/production is not only about making and/or developing a product from recyclable and environmentally friendly materials, but also about the extent to which the consumption of such a product contributes to pollution reduction or has a low level of pollution impact. It also includes sourcing and procurement of products in a green manner, which entails internal drivers including the desire to reduce costs by a reduction of waste, pollution, brand damage or litigation, and external drivers of social compliance and regulation. Furthermore, labels and certifications simplify green procurement as they set standards but introduce auditing and monitoring burdens on the buying side (Grant et al., 2017). The latter was confirmed by Chkanikova (2016), who investigated Swedish, British and Danish supermarkets to determine what type of purchasing relationships are more favourable for greening product supply. She found such relationships are dependent on characteristics of the procurement context, i.e. the presence of well-established certification schemes and the purchaser's interpretation of the power state dependence with suppliers. Thus it is important that marketers educate consumers, so they may develop a mentality that allows them to become aware of the benefits of the goods about to be purchased - and their provenance. By providing the target segment with precise information, their behaviour can be shaped as people have become more careful about the details that green products have on the package and/or in the product description, such as ingredients, components, manufacturing processes, standards, certification, etc. (Kordshouli et al., 2015).

Green price is frequently associated with an individual's willingness to pay a premium price for green or organic products. As price plays a decisive role in a consumer's decision-making processes and influences their satisfaction, it is obvious that the benefits and advantages to be gained by consumers must surpass the financial amount paid for the product (Herrmann et al., 2007). If the advantages of an item derived from its consumption, usage or possession exceed a consumer's expectations, he or she will be willing to pay a premium price, repurchase, retry and/or recommend the product in the future and thus exhibit loyalty to the green product. Otherwise, the chances of generating loyalty will diminish considerably as will the possibility of repeating future purchases (Pop and Dabija, 2013).

Green placement is heavily dependent on and exerts growing pressure on green supply chains. This is due primarily to the fact that a significant number of environmental challenges and problems are generated by processes of logistics conducted by organisations, such as manufacturing or sourcing (Eltayeb et al., 2011; Grant et al., 2017b). Therefore, companies with a negative public image or accused of conducting business in violation of environmental regulations, tend to be confronted with a drop in the number of customers, which naturally has an unfavourable impact on green satisfaction.

Green promotion focuses on various promotional norms adopted by companies and brought to the attention of consumers through packaging, promotional spots/ advertisements and other initiatives to achieve differentiation from competitors (Kordshouli et al., 2015; Vatamanescu et al., 2017). This provides evidence to consumers that companies care about the environment and at the same time are trying to empathize with the concerns of their consumers.

\subsection{Proclivity for environmental protection}

The proclivity for environmental protection is closely correlated with an individual's behavioural intentions (Konuk et al., 2015), which depend on the existence of green purchase intentions, a desire to pay more for green products (Pop and Dabija, 2013) and a desire to promote or present them in a good light to other people (e.g. word-of-mouth) (Zeithaml et al., 1996). When these three conditions are met and put into practice, i.e. by activating a conative behaviour component of attitudes, consumers exhibit a favourable predisposition towards protecting the environment. Consumers' attitudes to environmental and sustainability issues depend greatly on their experience and the resources they possess, i.e. their concern for such issues is based on the gap between the limited resources they possess and their own desires (Choshaly, 2017). As they are faced with various life situations and contexts and the traditional and green product purchase and consumption experience is improved, consumers are more and more aware of the need to protect the environment, the environmental issues affecting goods and companies, and negative impacts on the environment when there is a failure to adopt environmentally friendly processes and implement precise quality standards. The concern for environment protection generates a proactive attitude among individuals expressed in an increasingly frequent preference for environmentally friendly products and the fostering of future green purchasing intentions (Choshaly, 2017).

Even if environmental protection issues have increasingly become part of daily social life in general, and of greenoriented consumers, in particular, the putting into practice of green attitudes does not always lead to environmental protection-oriented behaviours. Culiberg and ElgaaiedGambier (2016) believe that the existence of environmental protection-oriented behaviour depends on situational and social factors: any individual's behaviour varies according to her or his available resources. A person sometimes pays more (i.e. a premium price) for green products if she/he wishes to have them or if she/he has the financial means. The adoption of such behaviour also depends on influences exerted by the person's reference group and on the attitudes of peers towards environmental protection. 
These actions are also important at the global level. For example, China is regarded as the country with the gravest pollution problems because of high gaseous emission levels. Specialists believe that this is the price paid by the country with the most impressive economic growth (Guo et al., 2013). The appearance of green products has greatly benefitted the Chinese people, representing a chance for improving their life. In fact, the Chinese view the purchase of green products as a means of improving the quality of life and of increasing the care for nature and the environment by reducing pollution. This laid the foundation for further economic development without lessening the chances of future generations having access to similar resources. Legislation was changed as well, with the result that the policies of the Chinese government focused on environment governance ( $\mathrm{Pu}$ and $\mathrm{Fu}, 2018$ ). The success of these Chinese policies is mirrored in the shift "from a centrally-planned economy to a market-oriented economy" (Li et al., 2018, p. 582). In the past, the Chinese economy focused on agriculture and its benefits, but now China is mostly an urban society, with its population concentrated in the large cities (Li et al., 2018). The shift from rural to urban environments led not only to greater pollution but also to a change in consumption behaviours. As they live in larger cities, people buy largescale products a lot more frequently than when consumption depended on autarchy.

Almost three-quarters of Europeans live in urban areas, with the result that excessive pollution sometimes has negative effects on the environment. Unlike China, the European Union acts a lot more swiftly to fight pollution and reduce gas emissions (Meijering et al., 2018). Local authorities are motivated to implement sustainable measures for example as, starting in 2008, the competition for the "European Green Capital Award" has been organised, in which European cities are assessed by how they live up to and apply environmental standards and other sustainable measures (Vasiliu et al., 2016; Meijering et al., 2018).

\subsection{Responsible consumption}

Responsible consumption is based on the premise that individuals make rational choices and thought-through decisions, i.e. they analyse purchases to diminish the likelihood that impulse purchases could have a negative impact on the environment (Schaefer and Crane, 2005). Responsible consumption centres around a consumer's fear about negative impacts on the environment and their own health and well-being, in addition to general societal effects. Responsible consumption is reflected in the activities of companies and people alike. Companies generate responsible consumption by obeying ethical norms and environmental protection legislation and by initiating social responsibility campaigns (Giesler and Veresiu, 2014). Such campaigns inform consumers to make them aware of negative effects from their decisions, as well as contribute to an increase in loyalty towards the company concerned.

Responsible consumption is a deliberate effort made by consumers based on values and beliefs acquired and adhered to over time (Ertz, 2016). The first step in exhibiting responsible consumption is a desire to recycle products to make a minimal contribution to the preservation of resources. Consumers understand the consequences of a product's resulting waste after it has fulfilled the major purpose for which it was created and purchased (A-Jalil et al., 2016). They also may deem it appropriate to find another use for the product or to use it to design a new product. Therefore, responsible consumption may be adopted hedonistically but it may also depend on the usefulness of the purchased product. While hedonism may encompass elements such as satisfaction or the pleasure generated by the act of purchasing itself, the utility components include the rationality of the purchasing decision or the functionality of the product (Adomaviciute, 2013). It is often the case that the latter category is the reason behind the amount paid for green products. This influences the consumer's purchasing decision, especially since the price of green products is higher and the consumers' behaviour is marked by the desire to pay more for such products.

The two-way approach according to which the welfare of a company turns on the welfare of consumers, is one of the theories behind the concept of 'responsible consumption' (Romani et al, 2014). On the other hand, consumers opt for responsible consumption early in the decision-making process and eliminate product alternatives that might have a negative impact on the environment and their health. Furthermore, the tendency to adopt such behaviour is a lot more pronounced among individuals when responsible consumption is a frequent habit of the members of their reference group.

Likewise, responsible consumption becomes binding upon people when viewed as a social norm, thus speeding up its acceptance by individuals. The actions to promote responsible consumption among consumers are conducted not only by non-governmental organisations, highly esteemed for their transparent and objective involvement (Romani et al., 2014), but also by companies and retailers that adopt and promote sustainability strategies and those concerned with the environment. Responsible consumption includes two major components: ethical consumption and environmental consumption (Adomaviciute, 2013). In turn, these components contain the implications of consumers' decisions - and those effects the actions of companies might generate when they fail to comply with legislative or ethical regulations.

Individuals display a tendency to adopt responsible consumption when the decision-making process and the purchase itself are viewed as a buying experience (Shobeiri et al., 2013). If the affective component of attitudes has a major role in choosing products, customers will think more about the possible problems that such goods may cause to the environment, as well as the impact of their purchasing decision on the preservation of resources, pollution reduction and the protection of the environment (Dabija et al., 2017).

\subsection{Green loyalty}

Green loyalty (Chen, 2010) measures a consumer's level of repurchasing intentions, accounting for a company's attitude to the environment and its commitment to promote sustainability. Two specific situations may appear, however. The first starts from the premise that consumers are only loyal to a company because they have no alternative (Kordshouli et al., 2015). In this case, loyalty is achieved under coercive conditions as the retailer is not the consumer's first choice. The second starts from the idea that consumer loyalty is the result of perceived satisfaction (Kordshouli et al., 2015). In this case, consumers prefer the products of the company regardless of how many competitors are in the market. This is a further incentive for companies to diversify their range of products to include green products and to develop new items in compliance with environment protection norms (Katait, 2014). 


\subsection{Summary and resulting hypotheses}

In summary, the development of green behaviours is based on the attention paid by companies to the environment and consumers (Thapa and Verma, 2014). This aspect is often considered by the management of companies as they are aware that protection of the environment is of paramount importance to a great number of consumers. Consequently, the companies' increasing concern for nature helps them increase their '4Ps' propositions to meet consumers' needs and achieve competitiveness in the current marketplace with the ultimate ambition of achieving ongoing consumer loyalty. The discussions in the preceding sections (2.1-2.4) are the bases for the development of the following three hypotheses:

- H1: Green behaviour positively affects a consumer's loyalty towards green-oriented retail formats;

- H2: A proclivity for environmental protection positively affects a consumer's loyalty towards green-oriented retail formats; and

- H3: Responsible consumption positively affects a consumer's loyalty towards green-oriented retail formats.

\section{Research methodology, demographic data and analytical methods}

\subsection{Survey design}

As this topic is relatively under-researched, we adopted an 'objectivist problematic' ontological and epistemological methodology after Cunliffe (2011). In this approach, reality is seen to exist independently as an entity or phenomenon. Such phenomena or objects can be studied to build generalised knowledge about systems, mechanisms, processes, patterns of behaviour, etc. Such knowledge can consequently be replicated and applied back to the world to improve it (i.e. a single hermeneutic). This methodology takes a macro perspective of studying consumers at a strategic and societal/environmental level and drawing generalisations about group and individual behaviours.

The method used was a survey-based quantitative exploratory study, using face-to-face questionnaire administration starting from the objective of the research, that is, highlighting the extent to which Romanian consumers, regardless of their age, develop 'green' loyalty towards four retail formats: food (i.e. grocery); electronichousehold appliances/accessories and information technology (i.e. computers and mobile phones); do-it-yourself (DIY), furniture; and interior design and apparel, footwear and sportswear, and based on the synergy of their green behaviours derived from their previous experiences with such products, the proclivity for environment protection and responsible consumption of goods. The research is based on the investigation of the relationships evident from the three hypotheses presented in section 2.5 above.

Approximately 3,400 questionnaires were administered in three development regions of Romania (Crisana, Centru and Banat), out of a total of eight regions, belonging to the historical region of Transylvania (with capital cities in Cluj-Napoca, Braşov and Timișoara), thus ensuring geographical representativeness of the sample (see Fig. 1). The interviewers were instructed in advance to approach respondents according to their gender and age (Churchill, 1991), to ensure representativeness according to the records in the Statistical Yearbook (2014). The faceto-face interviews were held in various public places, in the proximity to stores, or at respondents' homes. Respondents expressed their level of agreement with the predetermined statements on a five-point Likert scale.

Among the stores frequently visited by respondents and from which they make their purchases, are those belonging to international and domestic food and nonfood retail chains. The classification of these stores is presented in Table 1. It is interesting that respondents pointed to some stores carrying mostly food products, such as hypermarkets, as their favourite stores for the purchase of consumer electronics and household products. This indicates that these retailers implement a strategy of assortment reorientation and expansion to attract as many consumers as possible.

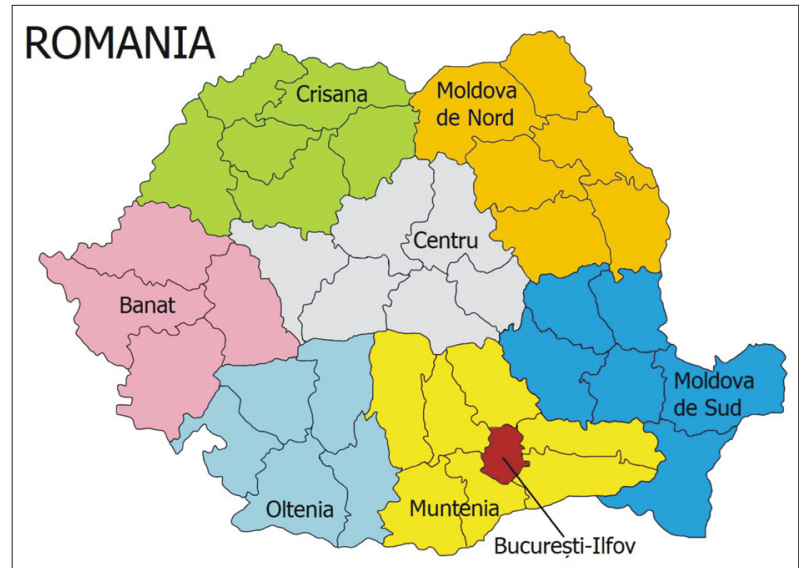

Fig. 1: Development regions and counties in Romania Source: authors' elaboration

\begin{tabular}{lll}
\hline Retail format & Romanian retail stores & International retail stores \\
\hline Fashion, sportswear and footwear & $\begin{array}{l}\text { Bigotti, Guara, Effect, Eponje, IQ, DH Sport, } \\
\text { Fashionsport, Benvenutti, Ameli, Marelbo, } \\
\text { Clujana }\end{array}$ & $\begin{array}{l}\text { Zara, Bershka, Stradivarius, New Yorker, C\&A, } \\
\text { H\&M, Calvin Klein, Hugo Boss, Lee Cooper, } \\
\text { Decathlon, Intersport, Hervis, Adidas, Nike, } \\
\text { Humanic, Ecco, Deichmann }\end{array}$ \\
DIY & $\begin{array}{l}\text { Ambient, Casa Rusu, Dedeman, Denver, Elvila, } \\
\text { King Art, Lems, Mobexpert, Nobila Casa }\end{array}$ & $\begin{array}{l}\text { Leroy Merlin, Bricostore, Hornbach, Ikea, Jysk, } \\
\text { Metro, Praktiker }\end{array}$ \\
Electronics products & $\begin{array}{l}\text { Altex, cel.ro, Domo, Emag, Flanco, Media } \\
\text { Galaxy, PC Garage, Satan }\end{array}$ & Auchan, Kaufland, Metro, Selgros \\
& Various Neighbourhood Stores & Auchan, Billa, Carrefour, Cora, Kaufland, Lidl, \\
\hline Food & & Penny, Profi \\
\hline
\end{tabular}

Tab. 1: Romanian and international retail stores chains

Source: authors' elaboration based on survey data 


\subsection{Operationalisation of variables}

When developing the questionnaire, the authors changed the theoretical latent constructs into manifest variables or meaningful statements for each construct considered. Green behaviour was measured based on four items: the impact of people's purchases on the environment, the extent to which their decisions are determined by care for the preservation of the environment, the extent to which they view themselves as responsible persons, and concern for the waste of natural resources (Lastovicka et al., 1999). Proclivity for environmental protection was measured against respondents' concern for complying with environmental protection regulations, the negative impact of the analysed retail business on the environment, and against respondents' desire to find out more information about the extent to which the purchased articles have a reduced environmental footprint (Antil and Bennett, 1979; Antil, 1984; Dabija et al., 2016). Responsible consumption was measured based on statements related to food and non-food product recycling behaviour, the repeated use of articles/products, and the need to use them in a more responsible way (Lastovicka et al., 1999; Haws et al., 2014). Romanians' loyalty to green retail formats was measured by respondents' intention and desire to revisit and recommend such stores, the proclivity for the purchase of green, organic products obtained from components that do not harm the environment, as well as the motivation to even travel a longer distance to buy such products (Nasir and Karakaya, 2014). The model subject to evaluation is presented as Figure 2.

\subsection{Testing the data for accuracy, reliability and internal consistency}

The data were systematically compiled, statistically tested and analysed with econometric software. Cronbach's $\alpha$ ( $>0.7$ ), item-to-total correlations, KMO criterion $(>0.7)$, Bartlett's test of sphericity and structural equation modelling (Churchill, 1991), were used to check the validity, reliability and internal consistency of data and test the relationships in the three hypotheses. Thus, the smallest value for Cronbach's $\alpha$ was obtained in the case of responsible consumption (0.789) consisting of three items, while the greatest value was recorded for loyalty towards green-oriented retail formats $(0.90)$ consisting of five items. The other two constructs, green behaviour, consisting of four items, and proclivity for environment protection, generated Cronbach's $\alpha$-values of 0.88 and 0.84 , respectively. Exploratory factor analysis revealed increased stability for each of the four constructs with the KMO criterion varying between 0.74 and 0.87 and the variance explained percentage ranging between $52.0 \%$ and $71.3 \%$.

We then subjected the items of the three investigated constructs (responsible consumption, green behaviour and proclivity for environment protection) to a single exploratory factor analysis (Walsh and Beatty, 2007). Based on the fit indices $(\mathrm{KMO}=0.92, \mathrm{KMO}>0.7, \chi 2=19,801.82$; $\mathrm{p}<0.001 ; \mathrm{df}=91$ ) that exceeded minimum threshold levels, the results confirmed the possibility to extract precisely three factors derived from the items of each analysed construct (Churchill, 1991; Forza and Filippini, 1998; Ju et al., 2006). The first factor with the largest eigenvalue (5.66) and 40.4\% variance explained is green behaviour, which has the greatest contribution to the variance reduction of the investigated phenomenon. It is followed by proclivity for environmental protection, having a smaller contribution to the explanation of the investigated phenomenon (eigenvalue $=1.69$;

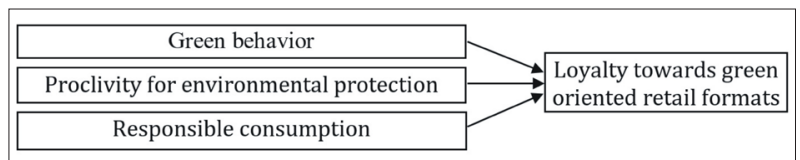

Fig. 2: The investigated model

Source: authors' conceptualisation

variance explained $12.0 \%$ ), and by responsible consumption (eigenvalue $=1.267, \quad$ variance explained 9.03\%). The next step was to determine, using the structural equation modelling software from SPSS (AMOS), the correlation between dependent and independent variables of the model (Fig. 2) for the four analysed retail formats (multi-group). The fit indices exceed the minimum acceptable thresholds specified in the literature $(>0.8 ; \leq 0.08)$ (Forza and Filippini, 1998; Ju et al., 2006), thus allowing the validation of the model and the interpretation of results.

\subsection{Sample structure}

The breakdown of respondents by the four retail formats was relatively evenly balanced (about 23\%), with a slight deviation being recorded in the case of fashion, sportswear and footwear retail (31\%). This is likely due to the random collection of data, as respondents were asked to name up to four favourite stores where they regularly go shopping. Each interviewer was instructed to make sure that at every fourth interview, an answer was provided for the first, the second, the third and the fourth store mentioned by a respondent. A greater number of opinions about fashion retail were obtained from women, likely due to their experience with fashion retailers and stores. In a similar study, Brough et al. (2016) confirmed that women have an eco-friendly attitude by getting involved in environment protection actions and choosing retailers for making purchases according to this attitude.

It is also interesting that a relatively large number of responses concerning electronics, household, information technology and accessories, furniture, DIY and interior design retail items were received from women. The latest societal consumption trends indicate that women are starting to express interest in, and want to know more details about such products, and they are visiting these stores likely as a response to retailers' strategies focused on enhancing hedonistic shopping orientations among female consumers (Otnes and McGrath, 2001; Teo and Sidin, 2014). Until recently, men showed a greater interest in issues related to the environment and environmental protection, but now more and more women show concern for these issues (Sima, 2014), helping to account for the results obtained in this research. Most respondents (84.7\%) in this survey are urban dwellers, and a relatively small number of responses was obtained from consumers living in rural areas ( $\mathrm{n}=517,15.3 \%)$. Most questionnaires were validated for the food retail responses, which concurs with the distribution of retail chains in Romania (found predominantly in urban areas and less in rural areas). The rural areas are almost exclusively targetted by food retailers that open small supermarkets or discount stores in villages with good custom (Dabija and Abrudan, 2015).

Almost one-third of the respondents live in three-person households (1,057 persons, 31.3\%) and prefer stores belonging to all retail formats. A significant number of responses was also obtained from persons living in oneperson households (4.7\%), who purchased mostly food and textile (clothes, footwear) products. Most individuals who 
assessed food retail stores have graduated from high school (12.9\%), while most respondents who assessed the other three retail formats have pursued higher education: 9.8\% respondents for DIY and furniture retail, $10.9 \%$ for electronic and household products retail; and $14.1 \%$ for fashion, sportswear and footwear retail. As the level of education increases, individuals acquire better training, boost their revenues and visit and prefer other stores beside the food stores. Aschemann-Witzel and Zielke (2017) highlight the fact that socio-demographic characteristics of individuals are more and more frequently the major element behind consumers' attitudes for the purchase of organic food.

When asked about their monthly net income earmarked for shopping, 625 persons (18.5\% of the sample) refused to provide any information. Most individuals in the sample earn a monthly net income between the national minimum wage (205 EUR) and the average wage (460 EUR), calculated at the time of the research. They make purchases from food (10.2\%), textile (12.6\%), electronic and household appliances (10\%) and DIY and furniture $(9.1 \%)$ stores. The persons with an income below the national minimum wage (205 EUR) accessed particularly the food stores $(4.6 \%)$, while those with an income over $2 \times$-average wages accessed especially the fashion and footwear (1.9\%), DIY and furniture (1.4\%) and electronic and household appliances (1\%) stores.

Only 21 participants in this research study stated that they bought food only several times a year $(0.6 \%)$. Most respondents analysed for this retail format (738 persons $-21.8 \%$ of the sample) visit super- and hypermarkets, proximity and discount stores on a weekly basis. The other retail formats are visited several times a year at the very most, whether they are DIY and furniture (307 persons), electronic and household appliances (403 persons), or fashion and footwear (481 persons) stores. A significant number of respondents stated they visited textile stores every week (217 persons), likely to keep abreast of the latest collections and to always find new fashion articles. This behaviour also confirms previous research (Dabija et al., 2014).
Despite the seemingly greater purchasing frequency in fashion stores, the amounts of money spent there are moderate, with 539 respondents spending below $20 \%$ of their income in DIY and furniture stores. This is comparable to the number of people making purchases from electronic and household appliances stores (512 persons) and fashion stores (568 persons). Respondents spend greater amounts of money on food products. Thus, 271 persons stated that the money spent in proximity stores, super- and hypermarkets amounted to $60 \%$ of their entire budget. Only 117 respondents spend between $41 \%$ and $60 \%$ of their budget in fashion, sportswear and footwear stores. This is reasonable because food represents the basic source for ensuring daily subsistence and, as such, people seek first to ensure their basic needs and then buy other non-food products (Swoboda et al., 2014; Dabija and Abrudan, 2015). In his research, Sima (2014) demonstrates that $26 \%$ of individuals are willing to pay up to $10 \%$ more to get the benefits of green products.

\section{Results and discussion}

The fit indices for the three hypotheses have values higher than the minimum acceptable thresholds $(>0.8 ; \leq 0.08)$, which allows for the validation of the model (Tab. 2) and the interpretation of results (Forza and Filippini, 1998; Ju et al., 2006).

Respondents' green loyalty to the four retail formats analysed is enhanced by the investigated behavioural dimensions. Consumers' proclivity for environmental protection has the strongest significant contribution in creating loyalty at the level of the four retail formats as a whole: $0.71(\mathrm{p}<0.001)$ in food, $0.60(\mathrm{p}<0.001)$ in DIY, furniture and interior design, $0.51(\mathrm{p}<0.001)$ in fashion, footwear and sportswear and $0.47(\mathrm{p}<0.001)$ in electronic and household appliances, information technology and accessories. This indicates that consumers are increasingly aware of the need to preserve resources and adopt green behaviour. The existence of responsible consumption at the level of all four retail formats, that is, the tendency to

\begin{tabular}{|c|c|c|c|}
\hline Sector (sample) / Effects & Correlation & Model fit & \\
\hline Food $(n=807)$ & & $\chi^{2}$ & $2,295.471$ \\
\hline Responsible consumption $\rightarrow$ Green Loyalty & $0.188^{* *}$ & $\mathrm{df}$ & 629 \\
\hline Green behaviour $\rightarrow$ Green Loyalty & $0.179 * * *$ & $\chi^{2 / d f}$ & 3.808 \\
\hline Proclivity for environment protection $\rightarrow$ Green Loyalty & $0.707^{* * * * *}$ & GFI & 0.926 \\
\hline Fashion $(n=1,068)$ & & AGFI & 0.911 \\
\hline Responsible consumption $\rightarrow$ Green Loyalty & $0.134^{* * *}$ & NFI & 0.925 \\
\hline Green behaviour $\rightarrow$ Green Loyalty & $0.314^{* * * *}$ & CFI & 0.944 \\
\hline Proclivity for environment protection $\rightarrow$ Green Loyalty & $0.508^{* * *}$ & TLI & 0.939 \\
\hline$D I Y(n=744)$ & & $* \mathrm{p}<0.1$ & \\
\hline Responsible consumption $\rightarrow$ Green Loyalty & $0.136^{*}$ & $* * \mathrm{p}<0.05$ & \\
\hline Green behaviour $\rightarrow$ Green Loyalty & $0.176^{* * *}$ & $* * * \mathrm{p}<0.01$ & \\
\hline Proclivity for environment protection $\rightarrow$ Green Loyalty & $0.595^{* * * *}$ & $* * * * \mathrm{p}<0.001$ & \\
\hline Electronics $(n=763)$ & & $\operatorname{RMSEA}(\leq 0.08)$ & \\
\hline Responsible consumption $\rightarrow$ Green Loyalty & $0.234^{* * * * *}$ & 0.0290 & \\
\hline Green behaviour $\rightarrow$ Green Loyalty & $0.236^{* * * *}$ & $\operatorname{SRMR}(\leq 0.08)$ & \\
\hline Proclivity for environment protection $\rightarrow$ Green Loyalty & $0.466^{* * * *}$ & 0.0507 & \\
\hline
\end{tabular}

Tab. 2: Green orientation and customer loyalty in food/non-food retail formats Source: authors' calculations 
recycle or lengthen the use of a fashion article or household appliance or the consumption of food shortly before expiry date, also contributes to the creation of loyalty to these retail stores but in a different way. The lowest impact is recorded in the case of fashion $(0.13 ;(\mathrm{p}<0.01)$ and DIY, furniture and interior design retail $(0.14 ; \mathrm{p}<0.1)$, while the intensity of the connection is greater in the case of food retail $(0.19 ; \mathrm{p}<0.05)$ and a lot stronger in the case of electronic and household appliances retail $(0.23 ; p<0.001)$. This varying impact probably depends on the type of goods analysed as the importance of these goods varies from one consumer to another.

Individuals' previous experience with, and favourable attitude towards sustainable and environmentally friendly products, that is, their green behaviour, varies greatly across the retail formats in creating green loyalty. The strongest impact is noticed in the case of fashion, footwear and sportswear retail $(0.31 ; \mathrm{p}<0.001)$ and the weakest impact, contrary to our expectations, was recorded in the case of food $(0.18 ; \mathrm{p}<0.01)$ and DIY-furniture $(0.18 ; \mathrm{p}<0.01)$ retail. In the case of electronic and household appliances retail, the impact is average in intensity but highly significant $(0.24 ; \mathrm{p}<0.001)$. The results seem to indicate that prior green experiences of respondents with fashion products is more important than the experience with food products in developing loyalty. A possible explanation could be that fashion items play a greater role in bringing social prestige as individuals can be seen wearing them, whereas the consumption of organic food is merely a matter of personal interest pursued only by those who can afford to pay a premium price.

\subsection{Food retail}

Several retail formats were selected for the category of food retail to be assessed by respondents: hypermarkets (Auchan, Cora, Carrefour), cash \& carry stores (Metro and Selgros), one 'category killer' (Kaufland), supermarkets (Profi, Billa, Carrefour market, etc.), proximity stores (Profi City, ABC stores, etc.). Their categorisation was made according to guidelines in the literature (Swoboda et al., 2014; Dabija and Abrudan, 2015). Consumers' green loyalty to the food retail formats is primarily determined by their tendency to share in environmental protection through the food they purchase $(0.71 ; \mathrm{p}<0.001)$. This intense and highly significant impact may be due to consumers' increased sensitivity to the food they consume (which has to be natural) and its source. A further argument is that consumers worry about their health. They want food that contributes positively to their health and general welfare (Pop and Dabija, 2013) and consequently seek to adopt and use green products to a greater and greater extent. Retailers providing society with a healthier life environment and consumers with the opportunity to maintain their health through the purchased goods, will secure a good position in the mind of individuals and differentiate themselves properly from their competitors (Kordshouli et al., 2015).

Food retailers have discovered that the choices made by consumers preferring green products can be shaped through information provided, as communication is a useful means of persuasion. In addition to the source of articles, the quality standards and certifications applied onto packages and labels, producers write more and more frequently about nutritional information designed to encourage the choice of healthier food (Mørk et al., 2017). The choice of organic foods is highly dependent on price as it can serve either as the main obstacle to the adoption of sustainable behaviour and the consumption of organics, or the main reason for choosing them given the benefits they have for health and their contribution to the environment.

Behaviour centred on the preference for sustainable (Dabija and Bejan, 2017) and/or environmentally friendly products can only serve as a prerequisite for the development of loyalty to the retailers offering organic products. Previous studies have shown that Romanians make efforts to consume more organic food, being more and more careful with what they purchase and consume, and expressing increased trust in the offer of health food stores carrying organic products or products obtained from sustainable trade. Having noticed this trend, many retailers have extended their assortment of organic food over the last few years (Pop and Dabija, 2013). Caring for one's health and welfare is seen as essential in making the decision to buy food, so that many consumers opt for green groceries (Sima, 2014).

Given the nature of food and its role in maintaining people's health, it is only natural that the selection of retailers and the adoption of loyal behaviour should be made by taking into account responsible consumption as well $(0.19 ; \mathrm{p}<0.05)$, whether it is about product recycling, the lengthening of product usage or making financial savings by optimising the products possessed or by postponing the purchase and/or consumption of a product (Dabija and Bejan, 2017). A significant and somewhat intensive influence on the creation of loyalty to the retail formats marketing green products is exerted by consumer green behaviour $(0.18 ; \mathrm{p}<0.01)$. An organic, green productoriented mentality, a high level of education fostering a positive attitude to green products and the acceptance of a premium price for organic products, as well as a consumer's previous experiences with such products, will lead to more rapid generation of loyalty among consumers. Women seem to purchase and consume organic food more than men (Ghosh et al., 2016), likely due to longer shopping periods and their planning, and to their concerns for maintaining their health and that of the entire family.

\subsection{Fashion, footwear and sportswear retail}

Respondents find it important that fashion articles be made of environmentally friendly components that do not pollute and do not foster the waste of resources. This condition must be met to develop their green loyalty $(0.51$; $\mathrm{p}<0.01$ ). The second dimension in terms of impact and significance is the existence of green behaviour ( 0.31 ; $\mathrm{p}<0.001$ ), that is, individuals' previous experiences and attitudes to environment protection and the preservation of resources. Consumers strive to contribute to the reduction of the impact of human activity on nature, and thus protect it by everything they do (their actions, decisions, etc.). As they exhibit such attitudes and orientation, it is easier to gain their loyalty and encourage them to return, revisit and purchase from retailers that manage to meet their objectives by the strategies they adopt. The results also reveal that the impact with the lowest intensity but sufficiently significant can be seen in the case of responsible consumption of fashion articles $(0.13 ; \mathrm{p}<0.01)$. As clothes enhance individuals' social status and prestige, they are less enthusiastic about using such articles for a longer period and recycling them. This appears to be a perspective on responsible consumption that is rather about purchasing products made of natural fibres or organic leather than wearing clothes for a longer period. 
Despite the increase of consumers' orientation towards green products, which helped this sector experience a great boom, Morgan and Birtwistle (2009) believe that this phenomenon is itself a contradiction. On the one hand fashion retail promotes the frequent consumption and appearance of new models and trends and, on the other hand, the green component is associated with durability, sustainability, reuse or recycling (Dabija et al., 2016). The adoption of this concept in the fashion industry is mostly due to interpersonal influence (Sadachar et al., 2016), that is, consumers belong to different reference groups and their values and norms are subservient to the values and norms promoted by the other members of the group. Therefore, the interaction between people and groups has the potential to shape an individual's behaviour and enhance her or his desire to obey the rules of the group to which she or he aspires to belong.

\subsection{DIY, furniture and interior design retail}

The strongest impact in building consumers' green loyalty to DIY, furniture and interior design retails was found to be in the degree of consumers' orientations towards environmental protection, expressed in their concern with the observance of ethical norms in this sector, the actual protection of the environment and the reduction of the impact of industry and trade with such products on the environment $(0.60 ; \mathrm{p}<0.001)$. Respondents always seem willing to have a minimum contribution to the achievement of this objective. On the other hand, the existence of behavioural prerequisites, opinions, knowledge and attitudes about the extent to which the individual may contribute to environmental protection also contributes to the creation of loyalty to the stores that adopt green strategies $(0.18 ; \mathrm{p}<0.01)$. The lowest impact in intensity and significance can be noticed in the case of responsible consumption $(0.14 ; \mathrm{p}<0.1)$, that is, individuals' willingness to recycle, reuse or extend the lifetime of the purchased goods. This may be the result of the fact that people rarely purchase such products and at the same time they (the products) are expected to exhibit longer durability than food or fashion products.

\subsection{Electronic, household appliances, IT and accessories retail}

For the electronics stores, all the investigated dimensions were found to have a strong and highly significant role in generating consumer green loyalty. While responsible consumption $(0.23 ; \mathrm{p}<0.001)$ and consumers' green behaviour $(0.24 ; \mathrm{p}<0.001)$ have a relatively similar, albeit strong, impact, respondents' proclivity for environment protection is twice as strong $(0.47 ; \mathrm{p}<0.001)$. The electronic devices, the household appliances, computers and the other IT accessories pose a relatively high potential for pollution if discarded and not recycled or properly collected.

It is likely that the various buy-back programs implemented by the analysed retailers in conjunction with sustainability and social responsibility strategies, encourage respondents to believe that the companies' efforts to gain their loyalty and have them adopt green behaviour and support responsible consumption are quite normal. This aspect, coupled with the fact that the recycling and green product consumption-oriented mentality is deeply embedded in the minds of respondents, contributes to the protection of the environment, and stimulates future preferences and search for the stores that implement sustainable practices. In fact, many stores belonging to this retail format collect used batteries and products for clean disposal, reducing the impact of the retailer's products on the environment (Dabija and Bejan, 2017).

\subsection{Verification of hypotheses}

From the preceding discussion, these results inform the hypotheses developed in Section 2.5. The first hypothesis (H1: Green behaviour positively affects a consumer's loyalty towards green-oriented retail formats): Green behaviour does indeed affect green loyalty, regardless of the retail format, but the influence is not very strong across all the considered retail formats. Fashion and electronics retail formats are affected more than food and DIY retail in this respect. Hypothesis 2 (H2: A proclivity for environmental protection positively affects a consumer's loyalty towards green-oriented retail formats) may be fully supported for all four retail formats, consistently with the highest effects. In food retail this effect is unusually high, probably because consumers are very much concerned about security and the long-term effects of foodstuffs on their health. Hypothesis 3 (H3: Responsible consumption positively affects a consumer's loyalty towards greenoriented retail formats) is also partially supported, the influence being higher in electronics retail than in the other three retail formats.

\section{Conclusions}

Respondents are concerned about the impacts of food and non-food trade and industry on the environment, and carefully watch the actual actions and measures adopted by retailers to diminish their own organic footprint and particulates, and regenerate the natural areas affected by production and transportation processes (Dabija et al., 2017). Responsible consumers are worried by the potential impact of their purchasing actions on the environment. By adopting responsible consumption, they strive to contribute to environment protection, being concerned not only with their own health and the purchase of goods that improve their welfare, but also with how the consumption of various goods ensures the access of future generations to living conditions like those of the present.

The results from this project reveal that, from the customer's perspectives, the generation of green loyalty varies across the studied retail formats. Therefore, behavioural antecedents have the strongest and most significant impact in generating this type of loyalty in electronic and household appliances retail. Most likely this is because Romanian consumers are a lot more aware of the potential negative impact of these goods on the environment, when such goods are not carefully collected or are not recycled. Consequently, they are more careful in the selection of retailers implementing an environmental protection-oriented sustainability strategy. In the case of fashion and footwear retail, however, the green loyalty of customers in this emerging market is affected more by their own green behaviours, which is a sign that Romanian consumers have started to realise the potential negative impact of the increased consumption of these articles on the environment. At the same time, it is possible that Romanians display green loyalty towards retailers that offer goods made of green and organic fibres or goods known to have been obtained by fair trade processes, without the exploitation of the working class in the countries of production. 
Satisfying and especially having consumers "cling" to the analysed retail formats seems to be a slightly more difficult task in the case of food and DIY retail. In these two retail formats, however, consumers' proclivity for environmental protection also plays an essential role in building green loyalty. This indicates that Romanian consumers are not insensitive to the products that are environmentally friendly - from what they eat and the extent to which such products are 'natural', to the goods/materials they use to build or decorate their houses.

It is important to note that, for the four retail formats analysed here, in general Romanians are increasingly aware of the need to adopt sustainable, green, nature-friendly behaviours which contribute, through the selection of specific products, to the preservation of resources and the environment. In other words, as retailers from mature markets have an increased presence in Romania, the green mindset of consumers in this market has become stronger (Pop and Dabija, 2013). They search for and buy more and more frequently not only the cheapest food and non-food products but also the green, environmentallyfriendly products made according to standards having consideration for environment protection. Therefore, Romanian consumers are starting to increasingly resemble their Western European peers, despite their still limited access to infrastructure, the range of goods on offer and the opportunities to make on-line purchases (Dabija and Grant, 2016; Grant et al., 2017a).

The theoretical contribution of this research is in highlighting the combined effects of responsible consumption, green behaviour and proclivity for environmental protection on green loyalty in retail, as well as the comparative analysis of these factors in four retail formats in an emerging market. Previous studies have also discussed various aspects of the development of a strong retail store brand (Swoboda et al., 2014) or the transfer of retail formats to emerging markets (Swoboda et al., 2017), but they did not take into consideration the green aspects.

We have also empirically demonstrated that there are some significant differences in generating consumers' green loyalty for the four retail formats. Our findings might help retailers operating in various retail formats in emerging markets better understand consumer actions, as well as the factors that might lead to green loyalty. Based on these findings, retailers could develop better market development strategies to attract more green-oriented consumers of various ages and educational levels, potentially increasing their success and market shares.

Among research limitations in this project are the relatively unequal number of respondents from the analysed retail formats, as well as the lack of comparative analyses, for example, with international versus domestic retail chains, or for the retailers implementing sustainability strategies versus those that do not. Future research directions may also consider the analysis of the sample according to its sociodemographic characteristics, or the analysis of other retailspecific elements (product assortment, ambience, personnel, etc.) in building green loyalty.

\section{Acknowledgment}

This work was supported by a grant of the Romanian National Authority for Scientific Research and Innovation, CNCS-UEFISCDI, project number PN-II-RUTE-2014-4-0312

\section{References:}

ADOMAVICIUTE, K. (2013): Relationship between Utilitarian and Hedonic Consumer Behavior and Socially Responsible Consumption. Economics and Management, 18(4): 754-760.

A-JALIL, E. E., GRANT, D. B., NICHOLSON, J. D., DEUTZ, P. (2016): Reverse logistics in household recycling and waste systems: A symbiosis perspective. Supply Chain Management: An International Journal, 21(2): 245-258.

ANTIL, J. A. (1984): Socially Responsible Consumers: Profile and Implications for Public Policy. Journal of Macromarketing, 4(fall): 18-39.

ANTIL, J. A., BENETT, P. D. (1979): Construction and Validation of a Scale to Measure Socially Responsible Consumption Behaviour. In: Henion, II, K.H., Konnear, T.C. [eds.]: The Conserver Society (pp. 51-68). Chicago, American Marketing Association.

ASCHEMANN-WITZEL, J., ZIELKE, S. (2017): Can`t Buy Me Green? A Review of Consumer Perceptions of the Behavior toward the Price of Organic Food. The Journal of Consumer Affairs, 51(1): 211-251.

ASGHARIAN, R., SALEHI, M., SALEKI, Z. S., HOJABRI, R., NIKKHESLAT, M. (2017): Green product quality, green customer satisfaction, and green customer loyalty, International Journal of Research in Management \& Technology (IJRMT), 2(5): 499-512.

BISSCHOFF, C. A., LIEBENBERG, P. (2016): Identifying Factors that Influence Green Purchasing Behavior in South Africa. Society for Marketing Advances, 174-189.

BROUGH, A. R., WILKIE, J. E., MA, J., ISAAC, M. S., GAL, D. (2016): Is Eco-Friendly Unmanly? The Green-Feminine Stereotype and Its Effect on Sustainable Consumption. Journal of Consumer Research, 43(4): 567-582.

CHEN, Y.-S. (2010): Towards Green Loyalty: Driving from Green Perceived Value, Green Satisfaction, and Green Trust. Sustainable Development, 21(5): 294-308.

CHERIAN, J., JACOB, J. (2012): Green marketing: A study of consumers' attitude towards environmentally friendly products. Asian Social Science, 8(12): 1-18.

CHKANIKOVA, O. (2016): Sustainable purchasing in food retailing: Interorganizational relationship management in green product supply. Business Strategy and the Environment, 25(7): 478-494.

CHOSHALY, S. H. (2017): Consumer Perception of Green Issues and Intention to Purchase Green Products. International Journal of Management, Accounting and Economics, 4(1): 66-79.

CHURCHILL, G. A. (1991): Marketing Research: Methodological Foundations. $5^{\text {th }}$ Edition, Fort Worth, The Dryden Press.

CULIBERG, B., ELGAAIED-GAMBIER, L. (2016): Going green to fit in - understanding the impact of social norms on pro-environmental behaviour, a cross-cultural approach. International Journal of Consumer Studies, 40(2): 179-185.

CUNLIFFE, A. L. (2011): Crafting qualitative research: Morgan and Smircich 30 years on. Organizational Research Methods, 14(4): 647-673. 
DABIJA, D. C., ABRUDAN, I. N. (2015): Retailing in Romania: From Statist to Nearly Capitalist. European Retail Research, 27(2): 55-92.

DABIJA, D. C., BĂBUŢ. R., DINU, V., LUGOJAN, M. (2017): Cross-generational analysis of information search based on social media in Romania. Transformations in Business \& Economics 16(2(41)): 248-270.

DABIJA, D. C., BEJAN, B. M. (2017): Behavioral Antecedents for Enhancing Green Customer Loyalty in Retail. In: Pamfilie, R., et al. [eds.]: BASIQ International Conference: New Trends in Sustainable Business and Consumption (pp. 183-191). Bucharest, Editura ASE.

DABIJA, D. C., GRANT, D. B. (2016): Investigating shopping experience and fulfilment in omnichannel retailing: A proposed comparative study in Romania and UK of generation Y consumers. In: Menachof, D. et al. [eds.] Proceedings of the $21^{\text {st }}$ Annual Logistics Research Network (LRN) Conference, University of Hull, September, e-proceedings.

DABIJA, D. C., POP, N.A., POSTELNICU, C. (2016): Ethics of the Garment Retail within the Context of Globalization and Sustainable Development. Industria Textilă, 67(4): 270-279.

DABIJA, D. C., POP, N. A., SZENTESI， S. (2014): A Customer-Oriented Perspective on Retail Brand Equity in the Fashion Industry. Industria Textilă, 65(1): 37-46.

DABIJA, D. C., POSTELNICU, C., DINU, V. (2018): CrossGenerational Analysis of Ethics and Sustainability. Insights from Romanian Retailing. In: Idowu, S. O., Sitnikov, C., Simion, D., Bocean, C. [eds.] : Current Issues in Corporate Social Responsibility. Thur, Springer International Publishing, pp. 141-163.

DO PAÇO, A., ALVES, H., SHIEL, C., FILHO W. L. (2013): Development of a green consumer behaviour model. International Journal of Consumer Studies, 37(4): 414-421.

DOSTER, L. (2013): Millennial teens design and redesign themselves in online social networks, Journal of Consumer Behaviour, 12(4): 267-279.

EASTMAN, J.K., IYER, R., LIAO-TROTH, S., WILLIAMS, D. F., GRIFFIN, M. (2014): The Role of Involvement on Millennials' Mobile Technology Behaviors: The Moderating Impact of Status Consumption, Innovation, and Opinion Leadership. Journal of Marketing Theory and Practice, 22(4): 455-470.

ELTAYEB, T., ZAILANI, S., RAMAYAH, T. (2011): Green supply chain initiatives among certified companies in Malaysia and environmental sustainability: Investigating the outcomes. Resources, Conservation and Recycling, 55(5): 495-506.

EPURAN, G., BRATUCU, G., BARBCULESCU, O., NEACSU, N. A., MADAR, A. (2018): Food Safety and Sustainability - A Exploratory Approach at the Level of the Romanian Wine Production Companies. Amfiteatru Economic, 20(47): 151-167.

ERTZ, M. (2016): Proposition of an Integrative Theory of Socially Responsible Consumption Behaviour. Electronic Green Journal, 1(39): 1-39.

FERNIE, J., GRANT, D. B. (2015): Fashion Logistics. London Kogan Page.
FERNIE, J., SPARKS, L. [eds.] (2014): Logistics and Retail Management ( $4^{\text {th }}$ ed.). London, Kogan Page.

FORZA, C., FILIPPINI, R. (1998): TQM impact on quality conformance and customer satisfaction: a causal model. International Journal of Production Economics, 55(1): 1-20.

GARCIA DE LOS SALMONES, M., CRESPO, A., RODRIGUEZ DEL BOSQUE, I. (2005): Influence of Corporate Social Responsibility on Loyalty and Valuation of Services. Journal of Business Ethics, 61(4): 369-385.

GHOSH, S., DATTA, B., BARAI, P. (2016): Modeling and Promoting Organic Food Purchase. Journal of Food Products Marketing, 22(6): 623-642.

GIESLER, M., VERESIU, E. (2014): Creating the Responsible Consumer: Moralistic Governance Regimes and Consumer Subjectivity. Journal of Consumer Research, 41(3): 840-857.

GRANT, D. B., DABIJA, D. C., COLICCHIA, C., CREAZZA, A., PHILIPP, B., SPENS, K., BĂBUT, R. (2017a): Expectations of Millennial consumers regarding online shopping and fulfilment. In: Gallagher, A. et al. [eds.]: Proceedings of the $22^{\text {nd }}$ Annual Logistics Research Network (LRN) Conference, Southampton Solent University, September, e-proceedings.

GRANT, D. B., TRAUTRIMS，A., WONG， C. Y. (2017b): Sustainable Logistics and Supply Chain Management (Second Edition). London, Kogan Page.

GUO, X., MARINOVA, D., HONG, J. (2013): China`s Shifting Policies towards Sustainability: a low-carbon economy and environmental protection. Journal of Contemporary China, 22(81): 428-445.

GURĂU, C. (2012): A Life-Stage Analysis of Consumer Loyalty Profile: Comparing Generation $\mathrm{X}$ and Millennial Consumers. Journal of Consumer Marketing, 29(2): 103-113.

HART, S. L. (1995): A Natural-Resource-Based View of the Firm. The Academy of Management Review, 20(4): 986-1014.

HAWS, K. L., WINTERICH, K. P., NAYLOR, R. W. (2014): Seeing the World through GREEN-tinted Glasses: Green Consumption Values and Responses to Environmentally Friendly Products. Journal of Consumer Psychology, 24(3): 336-354.

HERRMANN, A., XIA, L., MONROE, K., HUBER, F. (2007): The influence of price fairness on customer satisfaction: an empirical test in the context of automobile purchases. Journal of Products \& Brand Management, 16(1): 49-58.

JAISWAL, D., KANT, R. (2018): Green purchasing behaviour: A conceptual framework and empirical investigation of Indian consumers. Journal of Retailing and Consumer Services, 41(C): 60-69.

JOHNSTONE, M. L., TAN, L. P. (2014): Exploring the Gap between Consumers' Green Rhetoric and Purchasing Behaviour. Journal of Business Ethics, 132(2): 311-328.

JOSHI, Y., RAHMAN, Z. (2015): Factors affecting green purchase behaviour and future research directions, 3(1-2): 128-143. 
JU, T. L., LIN, B., LIN, C., KUO, H. J. (2006): TQM critical factors and $\mathrm{KM}$ value chain activities. Total Quality Management, 17(3): 373-393.

KANG, S., HUR, W. M. (2012): Investigating the Antecedents of Green Brand Equity: A Sustainable Development Perspective, Corporate Social Responsibility Environmental Management, 19(5): 306-316.

KATAIT, S. K. (2014): Green Marketing in India and its Impact on Consumer Behaviour. International Journal of Research in Commerce \& Management, 5(12): 71-74.

KIRMANI, M. D., KHAN, M. N. (2016): Environmental Concern to Attitude towards Green Products: Evidences from India. Serbian Journal of Management, 11(2): 159-179.

KONUK, F. A., RAHMAN, S. U., SALO, J. (2015): Antecedents of green behavioral intentions: a cross-country study of Turkey, Finland and Pakistan. International Journal of Consumer Studies, 39(6): 586-596.

KORDSHOULI, H. R., EBRAHIMI, A., ALLAHYARI BOUZANJANI, A. (2015): An analysis of the green response of consumers to the environmentally friendly behaviour of corporations. Iranian Journal of Management Studies, 8(3): 315-334.

LAN, S. (2014): An Importance-Performance Analysis of Multigenerational Preferences in Guestroom Technology. UNLV Theses, Dissertations, Professional Papers, and Capstones. Paper 2620.

LASTOVICKA, J., BETTENCOURT, L., HUGHNER, R., KUNTZE, R. (1999): Lifestyle of the Tight and Frugal. Journal of Consumer Research, 26(1): 85-98.

LI, Y., JIA, L., WU, W., YAN, J., LIU, Y. (2018): Urbanization for Rural Sustainability - Rethinking China`s Urbanization Strategy. Journal of Cleaner Production, 178: 580-586.

LIA, K. H., CHENG, T. C. E., TANG, A. K. Y. (2010): Green retailing: Factors for success. Californian Management Review, 52(2): 6-31.

MEIJERING, J. V., TOBI, H., KERN, K. (2018): Defining and measuring urban sustainability in Europe: A Delphi study on identifying its most relevant components. Ecological Indicators, 90: 38-46.

MORGAN, L., BIRTWISTLE, G. (2009): An investigation of young fashion consumers' disposable habits. International Journal of Consumer Studies, 33(2): 190-198.

MØRK, T., GRUNERT, K. G., FENGER, M., JUHL, H. J., TSALIS, G. (2017): An analysis of the effects of a campaign supporting use of a health symbol on food sales and shopping behaviour of consumers. BMC Public Health, 17(1): 1-11.

NASIR, V. A., KARAKAYA, F. (2014): Underlying Motivations of Organic Food Purchase Intentions. Agribusiness, 30(3): 290-308.

OTNES, C., MCGRATH, M.A. (2001): Perceptions and Realities of Male Shopping Behaviour. Journal of Retailing, 77(1): 111-137.

POP, N. A., DABIJA, D. C. (2013). Development of an organic food mentality in Romania. In: Thomas, A. R., Pop, N., Bratianu, C. [eds.]: The Changing Business Landscape of Romania (pp. 45-60). Springer, New York, NY.
PU, Z., FU, J. (2018): Economic growth, environmental sustainability and China mayors' promotion. Journal of Cleaner Production, 172: 454-465.

REGIO (2018): The Development Regions of Romania [online]. [cit. 20.06.2018]. Available at: http://www. cniptmoldovanoua.ro/index.php/ro/harti/harta-regiuniromania

RESHMI, R., JOHNSON, B. (2014): A study on the buying behaviour of green products. International Journal of Research in Commerce \& Management, 5(12): 39-45.

ROMANI, S., GRAPPI, S., BAGOZZI, R. P. (2014): Corporate Socially Responsible Initiatives and Their Effects on Consumption of Green Products. Journal of Business Ethics, 135(2): 253-264.

SADACHAR, A., KHARE, A., MANCHIRAJU, S. (2016): The Role of Consumer Susceptibility to Interpersonal Influence in Predicting Green Apparel Consumption Behavior of American Youth. Atlantic Marketing Journal, 5(1): 1-15.

SARKIS, J., GONZALEZ-TORRE, P., ADENSO-DIAZ, B. (2010): Stakeholder Pressure and the Adoption of Environmental Practices: The Mediating Effect of Training. Journal of Operations Management, 28(2): 163-176.

SCHAEFER, A., CRANE, A. (2005): Addressing sustainability and consumption. Journal of Macromarketing, 25(1): 76-92.

SHOBEIRI, S., RAJAOBELINA, L., DURIF, F., BOIVIN, C. (2013): Experiential motivations of socially responsible consumption. International Journal of Market Research, 58(1): 119-139.

SIERRA, V., IGLESIAS, O., MARKOVIC, S., JIT SINGH, J. (2015): Does Ethical Image Build Equity in Coporate Services Brand? The Influence of Customer Perceived Ethicality on Affect, Perceived Quality, and Equity. Journal of Business Ethics, 1-16.

SIMA, V. (2014): Green Behaviour of the Romanian Consumers. Economic Insights - Trends and Challenges, 66(3): 77-89.

SWOBODA, B., BERG, B., DABIJA, D. C. (2014): International Transfer and Perception of Retail Formats: A comparison Study in Germany and Romania. International Marketing Review, 31(2): 155-180.

SWOBODA, B., MORBE, L., DABIJA, D. C. (2017): International transfer and perception of retail formats An inter- and intra-format comparison study in Germany, France and Romania, Marketing ZFP - Journal of Research and Management, 39(4): 24-36.

TEO, C. B. C., SIDIN, S. M. (2014): Development and Validation of Female Hedonic Orientation Scale. Procedia - Social and Behavioral Sciences, 130: 390-399.

THAPA, S., VERMA, S. (2014): Analysis of Green Marketing as Environment Protection Tool: A Study of Consumer of Dehradun. International Journal of Research in Commerce \& Management, 5(9): 78-84.

VASILIU, C., FELEA, M., ALBASTROIU, I., DOBREA, M. (2016): Exploring Multi-Channel Shopping Behaviour Towards IT\&C Products, Based on Business Students Opinion. Amfiteatru Economic, 18(41): 184-198.

VATAMANESCU, E. M., NISTOREANU, B. G., MITAN, A. (2017): Competition and Consumer Behaviour in the Context of the Digital Economy. Amfiteatru Economic, 19(45): 354-366. 
WALSH, G., BEATTY, S. E. (2007): Customer Based Corporate Reputation of a Service Firm: Scale Development and Validation. Journal of the Academy of Marketing Science, 35(1): 127-143.

YOUNG, E. (2015): How Millennials Get News: Inside the Habits of America's First Digital Generation, Chicago, Associated Press-NORC Center for Public Affairs Research \& American Press Institute.
YOUNG, W., HWANG, K., MCDONALD, S. OATES, C. J. (2010): Sustainable consumption: green consumer behaviour when purchasing products. Sustainable Development, 18(1): 20-31.

ZEITHAML, V., BERRY, L., PARASURAMAN, A. (1996): The Behavioral Consequences of Service Quality. Journal of Marketing, 60(2): 31-46.

\section{Please cite this article as:}

DABIJA, D. C., BEJAN, B. M., GRANT, D. B. (2018): The impact of consumer green behaviour on green loyalty among retail formats: A Romanian case study. Moravian Geographical Reports, 26(3): 173-185. Doi: 10.2478/mgr-2018-0014. 